Santana-Cordero A. M. (2021). Geographic information science in historical landscape studies. GeoFocus, Revista Internacional de Ciencia y Tecnología de la Información Geográfica (Artículos), 28, 121-133. http://dx.doi.org/10.21138/GF.736

\title{
GEOGRAPHIC INFORMATION SCIENCE IN HISTORICAL LANDSCAPE STUDIES
}

\author{
AARÓN MOISÉS SANTANA-CORDERO \\ Instituto Universitario de Análisis y Aplicaciones Textuales - IATEXT \\ Universidad de Las Palmas de Gran Canaria. C/ Pérez del Toro, 1 - 35003 Las Palmas de Gran Canaria. \\ Spain \\ aaron.santana@ulpgc.es
}

\begin{abstract}
The use of geographic information science in historical landscape studies at the theoreticalmethodological level constitutes a clear scientific gap that needs to be filled. This work explores this field, considering important issues in relation to spatio-temporal analyses and integration, as well as the sources and the main techniques which can be used. A brief description and explanation is provided of photointerpretation, vector, raster and remote sensing techniques as useful tools for spatial analysis in historical landscape studies. Finally, an overview of the field is given through several examples of case studies and theoretical-methodological publications, providing in this way a brief state-of-the-art.
\end{abstract}

Keywords: spatial analysis; integration; comparison; combination; geostatistics; modelling.

\section{CIENCIA DE LA INFORMACIÓN GEOGRÁFICA EN LOS ESTUDIOS HISTÓRICOS DEL PAISAJE}

\section{RESUMEN}

El uso de la ciencia de la información geográfica en los estudios históricos del paisaje a nivel teórico-metodológico constituye una clara laguna científica que necesita ser solventada. Este trabajo explora dicho campo, considerando importantes cuestiones en relación con los análisis espacio temporales y de integración de fuentes y métodos, así como las fuentes y las principales técnicas que pueden ser usadas. De esta manera, se proporciona una breve descripción y explicación de la fotointerpretación, y de las técnicas vectorial, ráster y de teledetección como herramientas útiles para el análisis espacial en los estudios históricos del paisaje. Finalmente, se presenta una visión de conjunto del campo abordado a través de varios ejemplos de casos de estudio y publicaciones teórico-metodológicas, proporcionando así un breve estado del arte.

Palabras clave: análisis espacial; integración; comparación; combinación; geoestadística; modelización. 
Santana-Cordero A. M. (2021). Geographic information science in historical landscape studies. GeoFocus, Revista Internacional de Ciencia y Tecnología de la Información Geográfica (Artículos), 28, 121-133. http://dx.doi.org/10.21138/GF.736

\section{Introduction}

Historical landscape studies clearly need further development in terms of methodological foundations in order to provide researchers with the means for accuracy and objectivity in the way the historical sources are analyzed, which are often difficult to interpret and/or correlate to results from other source types. In this respect, the combination of methodological contributions of fields related to historical landscape studies is a key question. In other words, researchers interested in historical landscape studies should take into account methodologies employed in related fields.

The above is demonstrable since spatial analysis has received little attention in the field of historical landscape studies, with just a very few case studies applying it. Likewise, there is a clear absence of theoretical and methodological perspectives on this topic. A quick query on SCOPUS returned a striking result, with only 40 documents found and all published in the last 20 years. The author key words used in the search were "spatial analys*" and "historic*", with documents limited to the areas of social sciences, environmental science, arts and humanities, earth and planetary sciences and agricultural and biological sciences (Scopus 2021). In light of this finding, the objective of this paper is to explore spatial analysis methods and their application and integration in the wide field of historical landscape studies.

The main disciplines considered to be related with historical landscape studies are landscape ecology, land change/systems science, landscape research, historical ecology, landscape history, historical geography and environmental history (Gautreau 2010; Hughes 2006; Kienast et al. 2007; McLeman et al. 2010). The first three in particular have made important contributions to spatial analysis. In landscape ecology, the concept of landscape patterns is based on the spatial dimension, with the area, perimeter and shape of land plots playing an essential role in their calculation and interpretation (Farina 2006; Gustafson 1998). Moreover, the integration or consideration of history in this discipline guarantees the incorporation of the temporal dimension (Tappeiner et al. 2020). Land change science is largely based on analyses of land use and land cover change. There has been considerable progress made in this discipline in parallel with advances in earth-observation technologies and a number of methodological-related challenges have been identified (Rindfuss et al. 2004; Turner et al. 2007). For its part, landscape research is importantly supported by photointerpretation and remote sensing techniques in their analyses (Zimmermann et al. 2007). It should be noted that all three disciplines also undertake landscape monitoring on the basis of spatial data, for which frequency or temporal resolution are crucial features.

A fundamental element in all the aforementioned disciplines is the concept of land change, along with the incorporation of different aspects of the changes that take place and the study of landscape trajectories and evolutions. According to Antrop (1998), the following questions arise about this concept: (1) change of what? (variable); (2) what is the frequency of change? (rate); (3) what is the magnitude of change? (size); and (4) what reference time frame is used? (study period).

An obvious link, and very related concept to the topic tackled by this work is the Historical geographic information systems (HGIS), that have become essential tools in historical landscape studies to introduce the temporal component and help answer these four questions. There are at least three key points that explain the importance of HGIS. The first concerns the integration in geographic information systems (GIS) of historical maps, which normally include information that cannot be found in other sources (Rumsey and Williams 2002). From a technical point of view, the need to create "a standardized process to assess map comparability in a systematic way", as stated by Loran et al. (2018), should be highlighted. 


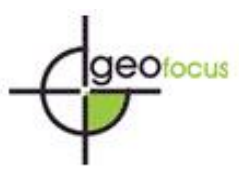

Santana-Cordero A. M. (2021). Geographic information science in historical landscape studies. GeoFocus, Revista Internacional de Ciencia y Tecnología de la Información Geográfica (Artículos), 28, 121-133. http://dx.doi.org/10.21138/GF.736

When dealing with hand-drawn maps from the past that are proportional to today's maps (i.e., proportional to reality), tasks that entail the georeferencing, measuring and registering of data and its integration with other geographical information can be performed in a GIS. Fuchs et al. (2015) explored the potential of using old maps and encyclopedias in the reconstruction of historic changes in European land cover/use. The results obtained can be added to the documentary evidence normally used in this type of study. The second key point is public (non-academic) involvement in HGIS (Lafreniere et al. 2019), allowing the transfer of knowledge from society to science through citizen participation in data collection tasks (Southall and Lafreniere 2019). Although volunteered geographic information has not yet been fully integrated in HGIS, perhaps because it is a relatively recent phenomenon (Budhathoki et al. 2008; Panek and Netek 2019), the broad public, and not only researchers, are becoming increasingly interested in spatio-temporal analyses (Andrienko et al. 2010). This is evidenced by the options available on various online geospatial platforms (e.g., Google Earth). Also important, as highlighted by Singleton and ArribasBel (2019), is the link between the fields of geography and data science, particularly with respect to socalled "big data" and the feedback that is generated in which volunteering plays an important role. Likewise, the field of history benefits from the spatial knowledge and contributions of the public. The third key point is that the implementation of an HGIS platform requires a significant amount of resources in terms of both time and money (Lafreniere et al. 2019). For example, the development and construction of a large geodatabase (a core feature of HGIS) is economically and temporally viable only in specific contexts, such as within a well-funded research project (Szabó et al. 2018).

\section{Central issues for spatio-temporal analyses}

Spatio-temporal analyses are essentially based on the: (1) comparison; (2) combination; and (3) generation of new data. All these procedures provide datasets that represent the changes that have taken place through new vector or raster layers and values.

\subsection{Comparison}

Comparisons involve the overlaying of historic maps and/or images (aerial photos and satellite imagery) of the same site in different years. They allow the extraction of data from the differences that exist between the documents being compared, and the registration and quantification of the changes (i.e., the different classes) of a given variable (e.g., land cover, land use, vegetation patches) in a landscape. Measuring them and calculating their differences and rates of change are basic operations, but with highly informative results. The results are not only presented spatially but also numerically, although always associated with the spatial dimension (e.g., GIS layer of plot area). For example, land cover layers of two or more years of the same area can be used to calculate the specific area, in each year, for all the classes present. Subsequently, a simple statistical treatment of the data will provide the area per land cover class in those years, as well as the quantified changes between them. In addition, with the magnitude and time component we can determine the rates of change of the studied variable. Another powerful resource is the transition matrix. This indicates all the change possibilities among the different classes (Xu et al. 2020), i.e., changes of class a to class b, class $\mathrm{c}$ and class d; changes of class b to class a, class $\mathrm{c}$, and class d, and so on. 
Santana-Cordero A. M. (2021). Geographic information science in historical landscape studies. GeoFocus, Revista Internacional de Ciencia y Tecnología de la Información Geográfica (Artículos), 28, 121-133. http://dx.doi.org/10.21138/GF.736

\subsection{Combination}

Combinations involve the use of two or more layers to perform spatial operations that are based on arithmetic or algebraic operations (i.e., map algebra in raster format). In this way, the location of each land change can be obtained - defined by boundaries in vector format - or their exact position in space in raster format - along time. Environmental trajectories based on different classes of the chosen variable can thus be established.

\subsection{Generation of new data}

New data can be generated through geo-statistics and modelling. These techniques allow several interesting research possibilities in relation to how the land used to be in the past. For example, data can be generated for a given year through statistical inference (past projection), and landscape modelling can be undertaken on the basis of ancient elements that remain on the land (e.g., heritage elements) for obtaining a complete surface with its values. The reconstruction of an environmental or human variable (e.g., rainfall or land use) with a series of data in a given timeframe is based on a statistical treatment of the data in terms of correlations (Kriesche et al. 2020). That is, inferences can be established in spatiotemporal terms. Historic trends and patterns can be used to help reconstruct landscapes beyond our own time frame. Even ancient cultural landscapes of premodern societies can be known with the aid of archaeological and/or paleo-environmental data (Kempf 2020). Geo-statistics allows new data to be obtained, while modelling can provide the depiction of an entire area from the spatially defined data of a given variable through interpolation.

\section{Integration issues}

Spatial data can differ in type (map, aerial photography, satellite imagery), nature (historical written data, pictures), time frame (archaeological or prehistorical, historical and current times) and/or thematic classification (e.g., Corine Land Cover (CLC) or Land Use Data Analysis (LUDA) (Riitters et al. 1995)). The different integrations that may be required are explained below (Fig. 1):

Temporal integration (horizontal integration; Fig. 1-a): the combination of sources that cover different historical periods. The need to construct long timelines with data of interest has led some authors to propose the integration of paleobiology, archaeology and history (Rick and Lockwood, 2013), or ecology and history (Hayashida, 2005). Sources such as archaeological data, historical maps and aerial photographs can be integrated in a GIS, enabling spatio-temporal analyses. This type of integration seeks to enlarge the timeframe of the study (e.g., Santana-Cordero et al. 2014). In this manner, the establishment of trends and trajectories of landscape changes over the course of various centuries and even millennia is feasible. Although such long-term analyses are not common in historical landscape studies (possibly in prehistoric landscape studies), they nevertheless constitute a theoretical issue of interest.

Multi-type integration (vertical integration; Fig. 1-b): the integration of a number of documents with different types of spatial data (e.g., historical map, topographic cartography, aerial photo and satellite imagery), as carried out by Hese et al. (2020). 
Santana-Cordero A. M. (2021). Geographic information science in historical landscape studies. GeoFocus, Revista Internacional de Ciencia y Tecnología de la Información Geográfica (Artículos), 28, 121-133. http://dx.doi.org/10.21138/GF.736

Multi-nature integration (Fig. 1-c): the integration of non-spatially-explicit information in a spatial framework. Historical written documents can contain descriptions about the location (even the coordinates) and characteristics of the land elements of interest, allowing the integration of archival sources or pictures into a map. Santana-Cordero et al. (2012, fig. 3), Trueman et al. (2013) and Santruckova et al. (2015) provide some examples.

Multi-thematic integration (Fig. 1-d): the procedure of equalizing the levels of the thematic content and spatial details of different sources (Petit and Lambin 2001), allowing application of the basics of a spatio-temporal analysis to them. In other words, it constitutes a way to harmonize or standardize the thematic data and the spatial resolution of two or more sources for an optimal thematic and spatial fit. One example is the procedure to adapt a LUDA dataset to CLC classes to facilitate the integration.

\section{A HORIZONTAL INTEGRATION}

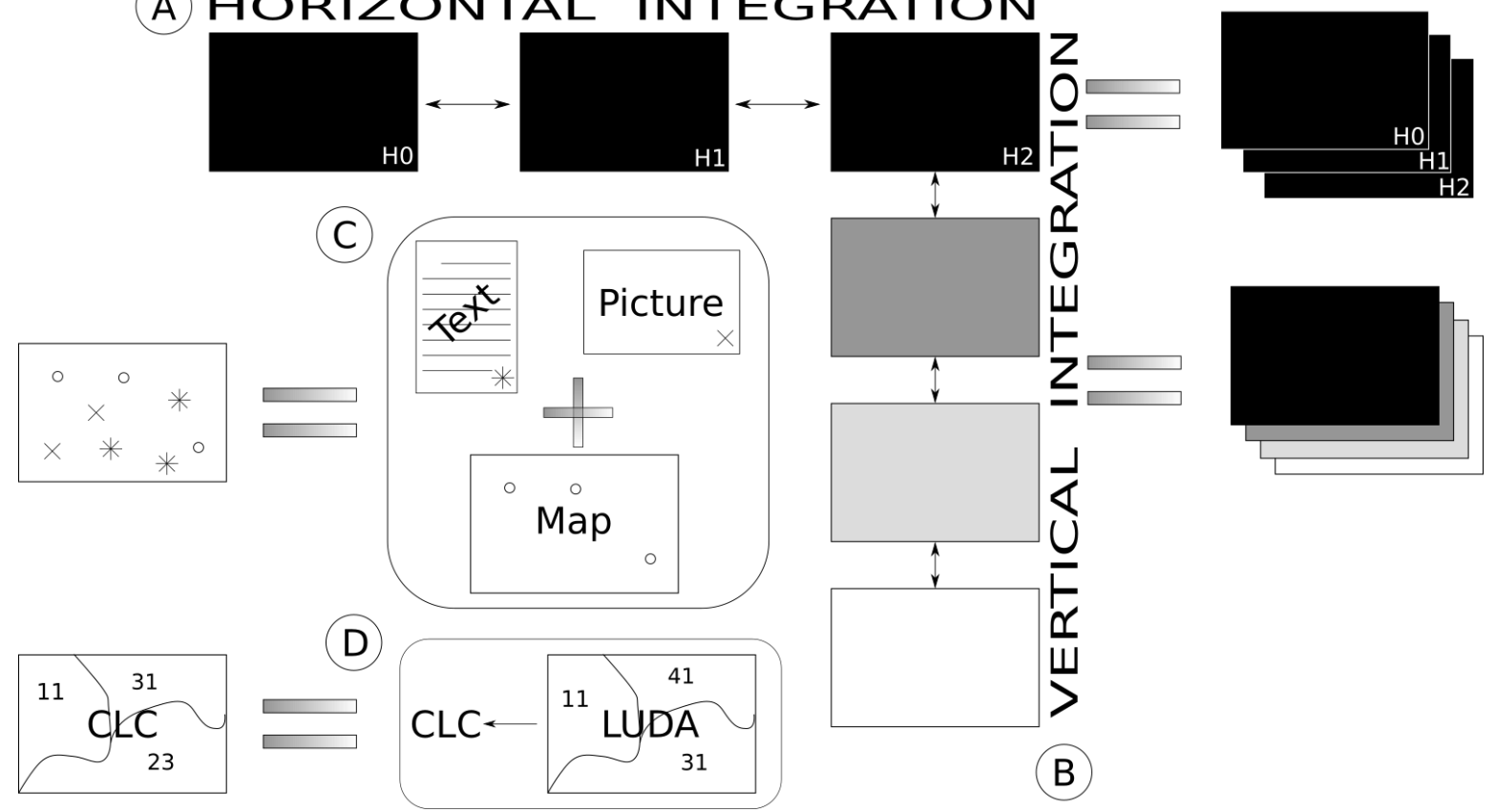

Figure 1. Graphical representation of the different types of integration.

\section{The sources: cartography, aerial photography, digital geographic information and satellite imagery}

Cartographic documents, especially historic maps, are extremely valuable sources of information to know how the land was centuries back. Historic maps can be proportional to the land or not (i.e., proportional to current cartography or not). The former case is interesting, as it allows the overlaying of different georeferenced maps, the taking of measurements, and the digitization and subsequent analysis of land elements. In the latter case, measurements cannot be made but overlaying remains possible with other similar maps without real spatial proportions in order to extract thematic information about the element of 
Santana-Cordero A. M. (2021). Geographic information science in historical landscape studies. GeoFocus, Revista Internacional de Ciencia y Tecnología de la Información Geográfica (Artículos), 28, 121-133. http://dx.doi.org/10.21138/GF.736

interest and make potential comparisons. However, such analyses are beyond the scope of this paper (for more information on these analyses see Santana-Cordero and Szabó 2019).

Aerial photography has become a very important (re)source for both land analysis and monitoring. The spatial and temporal extension and high accessibility of aerial photographs - Spatial Data Infrastructures (SDI) provide them, sometimes via a Web Map Service (WMS) - underline their importance. Indeed, modern cartography and digital geographic information are dependent on it, acting as a primordial source of information for land representation. The availability of aerial photography from as far back as the 1930s (for some places) to current times (Morgan et al. 2010) is extremely useful when undertaking diachronic studies that focus on and analyze one or more variables (e.g., land cover, land use and/or vegetation patches).

Digital geographic information comprises a set of digital GIS layers that provide data on different land characteristics. Such information is often created by researchers themselves and made available to others. This kind of information can be found on the Internet at different levels and scales: global, continental and national/regional. The information provided can contain many variables which can be spatially represented (including land cover, land use, soil type, vegetation patches, cadastral data, heritage elements, regional planning information, etc.), giving the researcher a significant input of data for analysis. The richness of such data also lies in its thematic dimension, above all with respect to the vector format in which each layer contains an attribute table that can have important information. In this regard, the raster format has its limitations, since a pixel generally represents just one value.

Satellite imagery is another important source of spatial information covering all the Earth with a high frequency and available in general terms from the 1970s onwards. It should be noted that the evolution of satellite platforms has improved the different resolutions of satellite imagery (spatial, spectral, radiometric). Furthermore, remote sensing (the treatment and analysis of satellite imagery) has its own issues and analytical procedures, highlighting the land classifications for diachronic analyzes.

Finally, it should be highlighted that SDIs are undoubtedly the best providers of spatial information sources. Collaborative cartography projects (e.g., OpenStreetMap), also accessible from a GIS, also constitute interesting platforms for spatial information advancement.

\section{The main techniques}

\subsection{Photointerpretation}

Photointerpretation constitutes the classical analysis technique for cartographic documents in geography and related disciplines. In a broad sense, it consists in the discrimination and identification of different patches (e.g., land cover, vegetation, etc.) and/or land elements through a set of criteria based on the characteristics of the image for a given variable. Morgan et al. (2010) list these criteria as tone or color, size, shape, texture, pattern, shadow, and site and context. Although photointerpretation has traditionally been carried out with aerial photographs in paper format, while the task today is essentially the same the researcher normally works on a computer screen, through a viewfinder or a GIS. This has the major advantage of enabling the data or land elements of interest to be digitized in the form of vector layers, as well as allowing the addition of their attributes and the preparation of the data to carry out spatio-temporal analyses. 
Santana-Cordero A. M. (2021). Geographic information science in historical landscape studies. GeoFocus, Revista Internacional de Ciencia y Tecnología de la Información Geográfica (Artículos), 28, 121-133. http://dx.doi.org/10.21138/GF.736

\subsection{Vector analyses - intersection}

An essential vector operation in historical landscape studies is the intersection, which allows comparisons to be undertaken. This operation involves the overlaying of two (or more) polygon layers, resulting in a new layer that contains all the polygons from the crossing of the former layers, and collecting the thematic data (fields of the attribute table) from them. "Vector intersection" is the procedure used to analyze landscape changes between two different dates, and is useful for the establishment of a transition matrix (Gerard et al. 2010; Xu et al. 2020). In such a matrix, it can be seen how the land cover of a particular landscape has changed, for example in terms of area and cover type, as well as the extension of an area that has changed to another land cover type. Using the second level of Corine Land Cover nomenclature by way of example, we can see how much area of one class (1.1) has gone to each of the other classes $(1.2,1.3,1.4,2.1$, etc. $)$ in two different years, and the same with the rest of the classes. It therefore allows a detailed exploration of all the changes and is useful for the establishment of landscape trends and trajectories based on land cover, land use or vegetation patches, landscape metrics, or other variables. In this way, change/persistence can be identified and measured in the resulting layer.

Also, the performing of landscape (ecology) metrics is proposed using vector data. These operations, which are normally done in raster format, use the number of grid pixels of each category to be calculated. This can be done by replacing the number of grid pixels of the total landscape and of each category (Turner et al. 2001) with the total area of the landscape and of each polygon, respectively. This practice opens up new possibilities for using vector data in an analysis typically performed with raster data.

\subsection{Raster analyses - map algebra, geo-statistics and modelling}

Raster data can be used to perform map algebra, geo-statistics and modelling through interpolation procedures.

Map algebra can be used, for instance, to count the number of times the pixels of a given area have changed through time. Since it is possible to detect if there has been a change or not through a simple vector intersection between two years for a given area, from here, rasterization on a binary raster ( 0 - no changes; 1 - change) and the summation of several binary rasters, gathering the $0-1$ values referring to other dates, gives us a final raster with 2 or more values (i.e. 0 changes, 1 change, 2 changes, 3 changes, etc.) with which landscape dynamism can be measured. Moreover, from a diachronic perspective, land cover change "hotspots" can in this way be identified, measured and studied in detail.

Landscape metrics, as mentioned above, are normally calculated from raster data. Studying landscape metrics in different years for a given study area allows us to know the degree of the temporal change of complexity, connectivity and other ecological processes commonly studied in landscape ecology (Farina 2006). An overview of this topic can be consulted in Gustafson (1998). A practical and useful plugin for QGIS called LecoS (Landscape Ecology Statistics) is available that makes these tasks easier when performing landscape metrics calculations.

For its part, geo-statistics can be used to make past projections for a given variable based on correlations and inferences towards the past. In this way, it is possible to explore the values of the studied variables beyond the timeframe availability of data. A past scenario can be reconstructed to know the characteristics of a given old or ancient area, thereby providing an important input to understand the temporal evolution of a landscape or ecosystem. 
Santana-Cordero A. M. (2021). Geographic information science in historical landscape studies. GeoFocus, Revista Internacional de Ciencia y Tecnología de la Información Geográfica (Artículos), 28, 121-133. http://dx.doi.org/10.21138/GF.736

In the case of modelling, the existence on land of ancient structures or heritage elements which are normally associated with land use allow spatial reconstructions to be carried out through interpolation procedures, enabling the generation of a past scenario of a given variable. One interesting possibility is a map of intensities according to closeness/remoteness among the elements modelled (e.g., a map of land use intensity).

\subsection{Remote sensing analyses - classifications and indices}

Remote sensing allows unsupervised and supervised classifications, among other types, to be made based on satellite imagery (Chuvieco 2019; Corbelle Rico and Crecente Maseda 2009). The comparison of the classification of a given area in two different years reveals the differences that exist between them. If the historical availability and resolution issues are known, it is possible to determine the suitability of these sources for the study area and period.

The study of a biophysical variable (e.g., vegetation status) offers the opportunity to uncover information for large areas about a specific topic which would not be possible by other means. By way of example, a researcher can determine the extent of the health of a forest through the NDVI (normalized differential vegetation index) and the spatio-temporal changes in this variable through the years, as well as examine any correlations between it and other known natural or human variables.

\section{Outlook: case studies applying geographic information science in historical landscape studies}

Although geographic information science (GISc) has not yet been fully integrated in historical landscape studies, some examples can be found in the literature that apply it in several forms. Some theoretical-methodological publications also shed light on GIS-based spatio-temporal analyses (Plumejeaud et al. 2011; Van de Weghe et al. 2014), although their development is beyond the scope of this work. In addition, Svenningsen et al. (2021) give some important insights into working with historical maps where context plays an essential role in the land use/cover categories. This can complicate direct comparisons with modern maps as multi-thematic integrations are required. For their part, Van de Weghe et al. (2014) proposed a continuous spatio-temporal model aimed at integrating both dimensions at multiple resolutions. Another interesting contribution is that of Levin et al. (2020) who explored an automated production for readable spatial datasets to detect land categories using Danish topographical maps from the late 1800s. Groom et al. (2021) developed a similar process to automatically digitize sand dunes from historic maps of northern Jutland (Denmark).

Using photointerpretation, Gautreau (2010) examined 251 land-survey charts for the period 18331860 that were georeferenced and integrated into a GIS. The aim was to explore the spatial distribution of different forest types and reconsider the dynamics of woody vegetation in the last two centuries in Uruguay. Shrubland descriptions taken from the written accounts of travelers/explorers were compared with current satellite-based maps of vegetation (from 2003), in this way practicing a form of multi-nature integration (see section "Integration issues"). Frajer et al. (2020) registered about 1,000 historical ponds currently integrated in the urban fabric of 43 cities in the Bohemia region of the Czech Republic, where many of them have been converted into other land covers or simply disappeared. Matasov et al. (2019) studied land use/cover change in the period 1770-2010 using historical maps, statistics and satellite imagery in Russia. Through modelling, McLeman et al. (2010) generated GIS-based precipitation and 
Santana-Cordero A. M. (2021). Geographic information science in historical landscape studies. GeoFocus, Revista Internacional de Ciencia y Tecnología de la Información Geográfica (Artículos), 28, 121-133. http://dx.doi.org/10.21138/GF.736

temperature models throughout their study area (Canada) from data series from the period 1901-2000. The aim was to identify the likelihood of drought conditions and combine the results with census data "to identify potential spatial associations between climatic conditions and population change". Kempf (2021) carried out a similar study on land cover change and desertification processes in northern China and Mongolia through multi-nature integration. Likewise, Krebs et al. (2012) created models to reconstruct the eco-cultural niche of giant chestnut trees in Switzerland strongly supported by statistical analyses of 65 environmental and cultural predictors. Domaas (2007) explored ancient tilled field patterns in Western Norway on the basis of 4 GIS layers: quaternary geology, distance from the hamlet, slope and folded aspect. A comparison was then made using these layers, which were overlaid to obtain a map with 4 categories, with 1 indicating the highest quality soil and therefore likely to be tilled. Through a LiDAR (lexicalized acronym for Light Detection And Ranging) analysis, Johnson and Ouimet (2021) calculated land use intensity in northeastern USA using data on relict charcoal hearths and stone walls as variables, obtaining the density over a $\mathrm{km}^{2}$ gridded layer. The variables used were also linked to widespread deforestation in the region. Ryavec (2001) designed a method to study changes in cultivated lands between 1830 and 1990 in central Tibet. The author used a Tibetan land decree (1830) and compared its data with current patterns.

As for landscape monitoring, Kienast et al. (2019) briefly described the program established in Norway in which GIS-based analyses of aerial photographs and other data are employed, and highlighted the significant positive correlations between social preferences and certain basic landscape metrics (number of land types, number of patches and land type diversity). For their part, Bayissa et al. (2019) created a model of drought derived from indicators obtained through satellite imagery in order to manage and monitor crops in Ethiopia.

\section{Concluding remarks}

Basic background, important concepts on spatio-temporal analysis, sources, the main techniques, and examples of the application of them in the scientific literature have been provided, with a thematic thread based on spatio-temporal analysis dimension in order to make a methodological contribution to the wide field of historical landscape studies.

This work has been based on the scant scientific literature available with the intention of providing an initial approximation to the integration of GISc in historical landscape studies. The main contribution of this study is the definition of the most important issues in spatio-temporal analyses and data integration. In this way, a general introduction to the topic is presented which can be developed and/or complemented with new contributions in the near future.

\section{References}

Andrienko, G., Andrienko, N., Demsar, U., Dransch, D., Dykes, J., Fabrikant S. I., Jern, M., Kraak, M. J., Schumann, H., Tominski, C. (2010). Space, time and visual analytics. International Journal of Geographical Information Science, 24(10), 1577-1600. https://dx.doi.org/10.1080/13658816.2010.508043

Antrop, M. (1998). Landscape change: Plan or chaos?. Landscape and Urban Planning, 41, 155-161. 


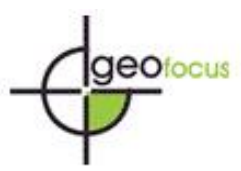

Santana-Cordero A. M. (2021). Geographic information science in historical landscape studies. GeoFocus, Revista Internacional de Ciencia y Tecnología de la Información Geográfica (Artículos), 28, 121-133. http://dx.doi.org/10.21138/GF.736

Bayissa, Y. A., Tadesse, T., Svoboda, M., Wardlow, B., Poulsen, C., Swigart, J., Van Andel, S. J. (2019). Developing a satellite-based combined drought indicator to monitor agricultural drought: a case study for $\begin{array}{lllll}\text { Ethiopia. } \quad \text { GIScience } \quad \text { Remote } & \text { Sensing, } & 56(5), & \text { 718-748. }\end{array}$ https://dx.doi.org/10.1080/15481603.2018.1552508

Budhathoki, N. J., Bruce, B., Nedovic-Budic, Z. (2008). Reconceptualizing the role of the user of spatial data infrastructure. GeoJournal, 72, 149-160. https://dx.doi.org/10.1007/s10708-008-9189-x

Corbelle Rico E., Crecente Maseda, R. (2009). Métodos para la clasificación automática de fotografías aéreas históricas en blanco y negro. GeoFocus, 9, 270-289.

Chuvieco, E. (2019). Teledetección ambiental: la observación de la Tierra desde el Espacio. Digital Reasons.

Domaas, S. T. (2007). The reconstruction of past patterns of tilled fields from historical cadastral maps using GIS. Landscape Research, 32(1), 23-43. https://dx.doi.org/10.1080/01426390601097511

Farina, A. (2006). Principles and Methods in Landscape Ecology: Towards a Science of Landscape. The Netherlands, Springer.

Frajer, J., Pavelková, R., Létal, A., Kopp, J. (2020). Relics and transformation of former ponds in the urban environment of the historical region of Bohemia (Czech Republic). Journal of Maps in press. https://dx.doi.org/10.1080/17445647.2020.1819900

Fuchs, R., Verburg, P. H., Clevers, J. G. P. W., Herold, M.. (2015). The potential of old maps and encyclopaedias for reconstructing historic European land cover/use change. Applied Geography, 59, 4355. https://dx.doi.org/10.1016/j.apgeog.2015.02.013

Gautreau, P. (2010). Rethinking the dynamics of woody vegetation in Uruguayan campos, 1800-2000. Journal of Historical Geography, 36(2), 194-204. https://dx.doi.org/10.1016/j.jhg.2009.06.016

Gerard, F., Petit, S., Smith, G., Thomson, A., Brown, N., Manchester, S., Wadsworth, R. et al. (2010). Land cover change in Europe between 1950 and 2000 determined employing aerial photography. Progress in Physical Geography, 34(2), 183-205. https://dx.doi.org/10.1177/0309133309360141

Groom, G., Levin, G., Svenningsen, S., Perner, M.L. (2021). Dune sand - object based image analysis for vectorization of a dotted signature in Danish late 1800s maps, in Tsorlini, A., Boutoura, C. (Ed.): Annual Conference Digital Approaches to Cartographic Heritage - Proceedings. Greece, pp. 207-216.

Gustafson, E. J. (1998). Quantifying landscape spatial pattern: what is the state of the art? Ecosystems, 1, 143-156.

Hayashida, F. M. (2005). Archaeology, ecological history, and conservation. Annual Review of Anthropology, 34, 43-65. https://dx.doi.org/10.1146/annurev.anthro.34.081804.120515

Hese, S., Kurepina, N., Walde, I., Tsimbalei Y. M., Plutalova T. G. (2020). Earth observation and mapbased land-use change analysis in the Kulunda steppe since the 1950s, in Frühauf, M., Guggenberger, G., Meinel, T, Theesfeld I, Lentz S (Ed.): KULUNDA: Climate Smart Agriculture. Switzerland, Springer, pp. 119-141.

Hughes, D. J. (2006). What is environmental history?. Cambridge, Polity Press. 


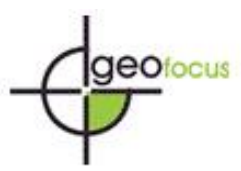

Santana-Cordero A. M. (2021). Geographic information science in historical landscape studies. GeoFocus, Revista Internacional de Ciencia y Tecnología de la Información Geográfica (Artículos), 28, 121-133. http://dx.doi.org/10.21138/GF.736

Johnson, K. M., Ouimet, W. B. (2021). Reconstructing Historical Forest Cover and Land Use Dynamics in the Northeastern United States Using Geospatial Analysis and Airborne LiDAR. Annals of the American Association of Geographers in press. https://dx.doi.org/10.1080/24694452.2020.1856640

Kempf, M. (2020). Fables of the past: landscape (re-)constructions and the bias in the data. Documenta Praehistorica, 47, 476-492. https://dx.doi.org/10.4312/dp.47.27

Kempf, M. (2021). Monitoring land cover change and desertification processes in northern China and Mongolia using historical written sources and vegetation indices. Climate of the Past in press. https://dx.doi.org/10.5194/cp-2021-5

Kienast, F., Wildi, O., Ghosh, S. (2007). Change and transformation: a synthesis, in Kienast, F., Wildi, O., Ghosh, S. (Ed.) A Changing World: Challenges for Landscape Research. The Netherlands, Springer, pp. $1-4$.

Kienast, F., Wartmann,F., Zaugg, A., Hunziker, M. (2019). A review of integrated approaches for landscape monitoring. Report, Council of Europe.

Krebs, P., Koutsias, N, Conedera, M. (2012). Modelling the eco-cultural niche of giant chestnut trees: new insights into land use history in southern Switzerland through distribution analysis of a living heritage. Journal of Historical Geography, 38, 372-386. https://dx.doi.org/10.1016/j.jhg.2012.01.018

Kriesche, B., Chaput, M. A., Kulik, R., Gajewski, K., Schmidt, V. (2020). Estimation of Spatio-Temporal Correlations of Prehistoric Population and Vegetation in North America. Geographical Analysis, 52, 371393. https://dx.doi.org/10.1111/gean.12214

Lafreniere, D., Weidner, L., Trepal, D., Scarlett, S. F., Arnold, J., Pastel, R., Williams, R. (2019). Public participatory historical GIS. Historical Methods, 52(3), 132-149. https://dx.doi.org/10.1080/01615440.2019.1567418

Levin, G., Groom, G. B., Svenningsen, S. R., Perner, M. L. (2020). Automated production of spatial datasets for land categories from historical maps, in Method development and results for a pilot study of Danish late-1800s topographical maps. Aarhus University, DCE - Danish Centre for Environment and Energy, 121 pp. Scientific Report No. 389 http://dce2.au.dk/pub/SR389.pdf

Loran, C., Haegi, S., Ginzler, C. (2018). Comparing historical and contemporary maps - a methodological framework for a cartographic map comparison applied to Swiss maps. International Journal of Geographical Information $\quad$ Science, $\quad 32(11), \quad 2123-2139$. https://dx.doi.org/10.1080/13658816.2018.1482553

Matasov, V., Prishchepov, A. V., Jepsen, M. R., Müller, D. (2019). Spatial determinants and underlying drivers of land-use transitions in European Russia from 1770 to 2010. Journal of Land Use Science 14 (46): 362-377. https://dx.doi.org/10.1080/1747423X.2019.1709224

Matteucci, S. D., Scheinsohn, V. (2004). Procesamiento de imágenes, SIG y modelos ecológicos aplicados a la arqueología. GeoFocus, 4, 93-109.

McLeman, R., Herold, S., Reljic, Z., Sawada, M., McKenney, D. (2010). GIS-based modeling of drought and historical population change on the Canadian prairies. Journal of Historical Geography, 36(1), 43-56. https://dx.doi.org/10.1016/j.jhg.2009.04.003 


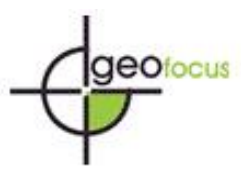

Revista Internacional de Ciencia y Tecnologia de la Información Geográfica

International Review of Geographical Information Science and Technology

Santana-Cordero A. M. (2021). Geographic information science in historical landscape studies. GeoFocus, Revista Internacional de Ciencia y Tecnología de la Información Geográfica (Artículos), 28, 121-133. http://dx.doi.org/10.21138/GF.736

Morgan, J. L., Gergel, S. E., Coops, N. C. (2010). Aerial photography: a rapidly evolving tool for ecological management. Bioscience, 60(1), 47-59. https://dx.doi.org/10.1525/bio.2010.60.1.9

Olaya, V. (2020). Sistemas de Información Geográfica. Published on the Internet under a Creative Commons license.

Panek, J., Netek, R. (2019). Collaborative Mapping and Digital Participation: A Tool for Local Empowerment in Developing Countries. Information, 10, 255. https://dx.doi.org/10.3390/info10080255

Petit, C. C., Lambin, E. F. (2001). Integration of multi-source remote sensing data for land cover change detection. International Journal of Geographical Information Science, 15(8), 785- 803. https://dx.doi.org/10.1080/13658810110074483

Plumejeaud, C., Mathian, H., Gensel, J., Grasland, C. (2011). Spatio-temporal analysis of territorial changes from a multi-scale perspective. International Journal of Geographical Information Science, 25(10), 1597-1612. https://dx.doi.org/10.1080/13658816.2010.534658

Rick, T. C., Lockwood, R. (2013). Integrating paleobiology, archeology, and history to inform biological conservation. Conservation Biology, 27(1), 45-54. https://dx.doi.org/10.1111/j.1523-1739.2012.01920.x

Riitters, K. H., O’Neill, R. V., Hunsaker, C. T., Wickham, J. D., Yankee, D. H., Timmins, S. P., Jones, K. B., Jackson, B. L. (1995). A factor analysis of landscape pattern and structure metrics. Landscape Ecology, 10(1), 23-39.

Rindfuss, R.R., Walsh, S. T., Turner II, B. L., Fox, J., Mishra, V. (2004). Developing a science of land change: challenges and methodological issues. Proceedings of the National Academy of Sciences of the United States of America, 101(39), 13976-13981. https://dx.doi.org/10.1073/pnas.0401545101

Rumsey, D., Williams, M. (2002). Historical maps in GIS, in Knowles, A. K. (Ed.): Past time, past place: GIS for History. Redlands (USA), ESRI Press, pp. 1-18.

Ryavec, K. E. (2001). Land use/cover change in central Tibet, c. 1830-1990: devising a GIS methodology to study a historical Tibetan land decree. The Geographical Journal, 167(4), 342-357.

Santana-Cordero, A. M., Monteiro-Quintana, M. L., Hernández-Calvento, L. (2012). Reconstrucción histórica de los usos del suelo en el desaparecido sistema de dunas de Guanarteme (Gran Canaria, Islas Canarias), clave para entender su dinámica espacio-temporal, in Barragán Muñoz, J. M., Verón, E., García Sanabria, J., García Onetti, J., Chica Ruiz, J. A. (Ed.): I Congreso Iberoamericano de Gestión Integrada de Áreas Litorales. Cádiz (España), Universidad de Cádiz, pp. 854-862.

Santana-Cordero, A.M., Monteiro-Quintana, M. L., Hernández-Calvento, L. (2014). Reconstructing the environmental conditions of extinct coastal dune systems using historical sources: the case of the Guanarteme dune field (Canary Islands, Spain). Journal of Coastal Conservation, 18, 323-337. https://dx.doi.org/10.1007/s11852-014-0320-5

Santana-Cordero, A. M., Szabó, P. (2019). Exploring qualitative methods of historical ecology and their links with qualitative research. International Journal of Qualitative Methods, 18, 1-11. https://dx.doi.org/10.1177/1609406919872112

Santrucková, M., Dostálek, J., Demková, K. (2015). Assessing long-term spatial changes of natural habitats using old maps and archival sources: a case study from Central Europe. Biodiversity and Conservation, 24, 1899-1916. https://dx.doi.org/10.1007/s10531-015-0912-x 


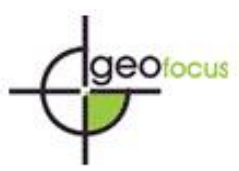

Santana-Cordero A. M. (2021). Geographic information science in historical landscape studies. GeoFocus, Revista Internacional de Ciencia y Tecnología de la Información Geográfica (Artículos), 28, 121-133. http://dx.doi.org/10.21138/GF.736

Scopus (2021) Available in: www.scopus.com Accessed: 29/04/2021

Singleton A., Arribas-Bel, D. (2019). Geographic data science. Geographical Analysis, 53(1), 61-75. https://dx.doi.org/10.1111/gean.12194

Southall, H., Lafreniere, D. (2019). Working with the public in historical data creation. Historical Methods, 52(3), 129-131. https://dx.doi.org/10.1080/01615440.2019.1629720

Svenningsen S., Perner, M. L., Levin, G., Groom, G. (2021). Investigating land area categories in largescale historical topographic maps in relation to analysing land use and land cover changes, in Tsorlini, A., Boutoura, C. (Ed.): Annual Conference Digital Approaches to Cartographic Heritage - Proceedings, Greece, pp. 164-178.

Szabó, P., Suchánková, S., Krízová, L., Kotacka, M., Kvardová, M., Macek, M., Müllerová, J., Brázdil, R. (2018). More than trees: the challenges of creating a geodatabase to capture the complexity of forest history. Historical Methods, 51(3), 175-189. https://dx.doi.org/10.1080/01615440.2018.1444523

Tappeiner, U., Leitinger, G., Zarina, A., Bürgi, M. (2020). How to consider history in landscape ecology: patterns, processes, and pathways. Landscape Ecology in press. https://dx.doi.org/10.1007/s10980-02001163-w

Trueman, M., Hobbs, R. J., Van Niel, K. (2013). Interdisciplinary historical vegetation mapping for ecological restoration in Galapagos. Landscape Ecology, 28, 519-532. https://dx.doi.org/10.1007/s10980013-9854-4

Turner, M. G., Gardner, R. H., O’Neill, R. V. (Eds.) (2001) Landscape Ecology in Theory and Practice: Pattern and Process. New York: Springer.

Turner II, B. L., Lambin, E. F., Reenberg, A. (2007). The emergence of land change science for global environmental change and sustainability. Proceedings of the National Academy of Sciences, 104(52), 20666-20671. https://dx.doi.org/10.1073pnas.0704119104

Van de Weghe, N., de Roo, B., Qiang, Y., Versichele, M., Neutens, T., de Maeyer, P. (2014). The continuous spatio-temporal model (CSTM) as an exhaustive framework for multi-scale spatio-temporal analysis. International Journal of Geographical Information Science, 28(5), 1047-1060. https://dx.doi.org/10.1080/13658816.2014.886329

Xu, L., Zhao, S., Chen, S. S., Yu, C., Lei, B. (2020). Analysis of arable land distribution around human settlements in the riparian area of Lake Tanganyika in Africa. Applied Geography, 125, 102344. https://dx.doi.org/10.1016/j.apgeog.2020.102344

Zimmermann, N. E., Washington-Allen, R. A., Ramsey, R. D., Schaepman, M. E., Mathys, L., Kötz, B., Kneubühler, M., Edwards, T. C. (2007). Modern remote sensing for environmental monitoring of landscape states and trajectories, in Kienast, F., Wildi, O., Ghosh, S. (Ed.) A Changing World: Challenges for Landscape Research, The Netherlands, Springer, pp. 65-91. 